\title{
連想のためのテンプレートを有するコネクショニスト モデルデータベースシステム
}

\author{
非会員 萩 原 将 文 (慶応大) \\ 非会員 安 西 䙃一郎 (慶応大)
}

\section{Connectionist Model Data Base System with a Template for Association} Masafumi Hagiwara, Non-member, Yuichiro Anzai, Non-member (Keio University)

Combination of Artificial Intelligence (AI) and Connectionist model is very effective to construct an intelligent information processing system. There are several studies based on such a concept. An example, a knowledge base system based on connectionist model has the following features.

(1) Robustness: even when there are some errors in a user's question or in a knowledge base, a near right answer can be obtained.

(2) Context dependency: retrieval with prediction is possible.

(3) Easy parallel retrieval for multiple concepts.

(4) Easy maintenance of knowledge base : facts are expressed by symbols.

In spite of the above advantages, the conventional system has a great shortcoming: it can only make inference of facts.

This paper proposes a connectionist model data base system with a template for association. The proposed system has two features: inference is possible when data is insufficient, and new knowl. edge can be generated by inference. The proposed system uses a template to create a network for associative reasoning, and it can be done by interactive activation and competition process. Computer simulation result indicates the effectiveness of the proposed system.

$$
\text { キーワード：コネクショニストモデル，データベース，連想 }
$$

\section{1.まえがき}

近年, 生体の脳の情報処理原理を模擬し, 多くの比 較的単純な基本要素を用いたネットワークメカニズム によって高度並列分散型の知的情報処理を行おうとす るコネクショニストモデルの研究が盛んになってい $ろ^{(1)}$ ここれまでにも, 音声認識(2)や文字認識(3), 最適 化(4)などにおいて優れた成果が発表されている。コ ネクショニストモデルは，あいまいな情報を报うのは 得意であるが, 論理的なデー夕を扱うのは比較的不得 意である。一方, 従来より計算機に記号処理や問題解決 を行わせようとする人工知能(AI; Artificial Intelligence) の研究がある。AIは, 論理的に推論可能な解答の導 出は非常に得意としている。しかし，不確かな推論や
直観による解答などといった論理の飛躍を含んだ推 論(5)などはかなり困難であり，今後の大きな課題と なっている。

以上より，コネタショニストモデルは比較的あいま いな情報を，AI は論理的なデータを扱うのを得意と していることがわかる。これらの両者を組合せて、よ り高度な知的情報処理を目指した研究が行われてい る。例えば，知識バースシステム(6)，言語処理システ 厶(7)(8)，エキスパートシステム(9)などがある。

これらのなかで特に, 文献(6)のコネクショニスト モデルを用いた知識バースシステムは，以下のような 多くの優れた点を有している。

（1）碩丈性 システム内の知識や，ユーザの䁈 問の中に多少の誤りが含まれていても，ほ涪正しい答 
を返すことができる。

（2）文脈依存性 検索に先立って，西らかじめ 検索結果に予測を与えることがてきる。

（3）複数の概念の並列検索が比較的容易である。

(4) 知識ベースの保守性 知識ベース内のファ クトを記号表現で与えているために，従来のコネクシ ヨニストモデルのみによるネットワークなどに比べて 知識ベースの保守性が優れている。

（5）ネットワークサイズの削減ユーザの㙺問 に関係のあるユニットのみを生成するので, 従来のコ ネクショニストモデルのみによるネットワークなどに 比べてネットワークの大きさを小さくできる。

しかし文献中でも述べられているように, ファクト の検索のほかには推論を行えないという, 知識ベース システムとしては大きな問題点があった(6)。そこで本 論文では，テンプレート構造をコネクショニストモデ ルに取入れることにより，連想による推論を行うこと のできるコネクショニストモデルデータベースシステ 么を提案する。な抢 $\mathrm{AI} の$ 分野に括いて，連想に比較 的似た概念として，“類推”がある。その研究は，海外 では, Winston ${ }^{(20)}$ やCarbonell ${ }^{(1)}$, 国内では, 原口 ら(12) などがある。提案システムは，AIによる手法と コネクショニストモデルによる手法とが組合されてい るため, 上記 (1)〜(5)の長所を兼极備えている。

本論文ではまず，第 2 章で従来型コネクショニスト モデルを用いたデータベースシステムの概要について 説明する。第 3 章では, 新しく提案する連想機能を有 するコネクショニストモデルデータベースシステムに ついて説明する。第 4 章では, 簡単なシミャレーショ ンによって提案方式の有効性を示す。

\section{2. 従来型コネクショニストモデルを用いた 知識ベースシステム}

本章では，コネクショニストモデルを用いた知識心゙ 一スシステムの概要について文献（6）に基づいて説明 する。

本シスデムは, Rumelhart'(1)らによる Interactive activation and competition モデルを基本形としてい る。大きく異なっている点は，ネットワークを初めか ら作っておくのではなく，知識ベース内のファクト集 合とスーザが求める検索要求から必要なネットワーク （変数制約ネットワーク）を動的に生成する点である。 このネットワークには，検索すべき概念の候補である 概念ュニットを集めた変数クラスタ（Variables clus. ter）と，変数の制約式に対応する制約二ニットを集 めた制約クラス夕 (constraint cluster) がある。同

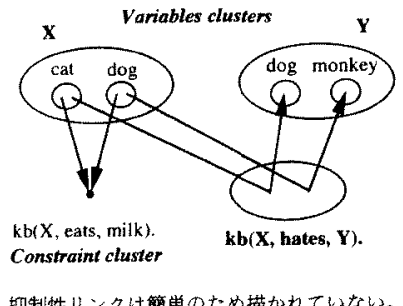

図 1 検索のために構成されるネットワータ

Fig. 1. Constructed network for information retrieval.

一のクラス夕内に含まれるユニットは，双方向の抑制 性のリンクで結合されている。また，それぞれの制約 ユニットとそれが満足する概念ニニットとの間には双 方向の興奮性リンクが張られている。なお, 動的にネ ットワークを構成するという手法は, 自然言語処理を 対象としている文献 $(8)$ でも用いられている。

知識バース内のデータはファクトの集合からなり, 各ファクトは,

$k b$ (概念, 属性名, 属性值)

の三つの組で表されている。例えば，まず以下のよう なファクトの集合が与えられているとする。

$k b$ (cat, hates, dog)

$k b$ (dog, hates, monkey)

$k b$ (cat, eats, milk)

$k b$ (dog, eats, milk)

ここで，コーザーが次のような概念の検索を要求した とする。

$\{k b(X$, eats, milk $), k b(X$, hates, $Y)\}$

このような場合には, 図 1 に示されるように, 変数 $X$ と $Y$ 二つの変数クラスタと, 二つの制約クラス タからなる变数制約ネットワークを構成する。そし て, 活性化昖散サイクル(1)(6)を繰返すことにより, 求 めたい概念が検索される。このように複数の变数クラ スタを制約クラスタで結合することにより, 複数の概 念の並列検索が北較的容易になっている。

\section{3. 連想機能を有するコネクショニストモデル データベースシステム}

〈3・1〉コネクショニストモデルを用いた推論 推論は, 論理的に推論可能なものと, そうでないも のとに大別することができる。人工知能 (AI; Artificial Intelligence) は, 諭理的に推論可能な解答 
の葚出は得意としているが，不確かな推論や直観によ る解答などといつた論理の飛躍を拿んだ推論などには 困難が伴う。一方，コネクショニストモデルは，論理 的な推論は比較的不得意であるが，逆にあまり論理的 でない推論，例えば“ひらめき”とが直観”などといつ たものを扱うのには適していると考えられる。

そこで本諭文では，その第一步として，コネクショ ニストモデルを利用して連想による推諭を方法を提案 する。AI技術に基づいて類推による推諭を行う方 法(10)(12) も提案されている。しかし，提案方式をコネ クショニストモデルデータベースシステム゙(6)に用い ることにより，以下のような優れた点をすべて有する データベースシステムが構築可能となる。

（1）元灭性が高い。

（2）文眽依存性を与えられる。

（3）複数の概念の並列検索が比較的容易である。

(4) データバースの保守性が, コネクショニスト モデルのみによるシステムより優れる。

〈3・2〉類推による推論の特徵提案方式は, “類 推”の考え方を基礎として構成されている。ここでは, それについて簡単に説明する。

類推とは，幾つかの与えられた対象間に類似性（類 比）を発見し，その類似性により一方の対象で成立す る事実や関係，操作法などのデー夕を他方のそれに変 換することにより，問題解決や未知の事実を予測推定 する推論方式の一種である(12)。

類推による推諭の特徴は, 推諭される事柄自体につ いてのデータが不足していても推諭が可能であり、柾 しろ推論の結果，新しいデータが生成されることであ る(1.3)。従って，デー夕の久如のために推論が行えな くなってしまったような場合でも，類推によって推論 を続行させるようなことが可能となる。このような頑 大性は，大量のデー夕を扱わなければならないデータ ベースシステムにとって大変都合のよいことである。

〈3・3〉コネクショニストモデルよる連想の原理 まず，類推による推論について例をあげながら簡単 に説明する。

例えば，次のようなファクトの集合，

$k b$ (cat, eats, mouse)

$k b$ (lion, eats, zebra)

$k b$ (cat, smaller than, lion)

が与光られている場合に, 次のような概念の検索が要 求さ机たとする。

$k b$ (mouse, smaller than, $X$ )

このとき,リスト (7), (8)より, ネコとライオ
ンおよびネズミとシマウマが対䒚していることがわ かり，リスト（9）功，ネコとライオンが“小さい” いう関倸にあることがあかるから，ネズミが“小さい” 関係にあるのはシマウマであると推論できる。このよ うな四つの関係に基づいて行う推論溹，類推による推 論と呼ばれている(13)。

以上のような場合, 従来の方式(6)では検索要求に 対灾するデータがないために全く対応できない。提案 方式では，四つの関係をテンプレート構造としてネッ トワーク上に構成して, 活性化拡散サイクル(3)(6)を繰 返すことにより，連想による推論(類推)を行う。

まず，類推の根拠になる四つの関係の連想のための テンプレート構造を次のように定める。

$k b(Y$, ATTRIBUTE_NAME, $a)$

$k b(Z$, ATTRIBUTE NAME, $X) \quad \cdots(12)$

$k b(Y$, attribute name, $Z)$

$k b(a$, attribute_name, $X)$

ここで，小文字で始まるアトム山定数を表してお り，大文字で始まるアトムは変数を表している。ま た，リスト(11)〜(14)は，それ林ト(7)〜(10)

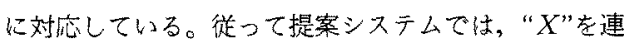
想するために，アトム“ATTRIBUTE_NAME”, ア

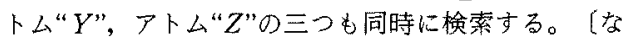
お，“組合せ的爆発”に対する考察は，〈4・2〉節(シミ ஃレーション結果执よび考察) 参照。)

図 2 に，リスト $(7) \sim(10) て ゙$ 示さ礼る例によって生 成されるネットワータを示す。

ネットワーク生成のアルゴリズムは以下のと扔りで ある。

連想ネットワーク生成アルゴリズム

(1) リスト(11)により，アトム“a”に関係するア

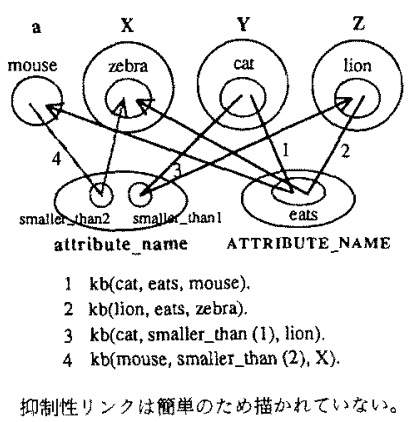

図 2 連想のために構成されるネットワーク

Fig. 2. Constructed network for association. 
トム“ATTRIBUTE_NAME”と，それに対応するア トム“Y”の二つの変数クラスタを作る。そして，各つ アクトに基づいて，对応するユニット間（" $Y$ ” "ATTRIBUTE_NAME"の間, “ATTRIBUTE_NAME" と“ $a$ ”の間）に双方向の與奮性のリンクを張る。

（2）リスト（13）により，アトム“attribute name" に関係するアトム“Z”の変数クラスタを作る。そし て各ファクトに基づいて，対応するユニット間 (" $Y$ "と"attribute_name"の間, "attribute_name"と “Z”の間) に双方向の興奮性のリンクを張る。

(3) リスト(12)により，アトム“Z”，アトム “ATTRIBUTE_NAME”に関係するアトム“ $X ” の$ 変 数クラスタを作る。そして各ファクトに基づいて，対 応するノード間（“Z”そ"ATTRIBUTE NAME”の 間, “ATTRIBUTE_NAME” “ $X ” の$ 間) に双方向 の與奮性のリンクを張る。

（4）各クラスタ内のユニット間に双方向の抑制性 のリンクを張る。

ただし，検索条件りスト[リスト(10)，(14)]を除 く, 同一クラスタ内に含まれる同名のアトムは，一つ のユニットを共有する。また, “ATTRIBUTE_ NAME”クラスタ内のユニットは制約ユニットである が, 変数となっているため, 概念ユニットと同様に扱 われる。

活性化搪散サイクルは，Rumelhartらによって提 案されている次のような方式を用いている(1)(6)。

まず，ユニット $i$ への入力和を次式で定義する。

net $_{i}=\sum_{j} w_{i j}$ output $_{j}+$ extinput ${ }_{i}$

ここで, $w_{i j}:$ ユニットjからユニットiへ

の重み, output ${ }_{j}:$ ユニト $j$ の出力, extinput $_{i}:$ ニニット $i$ への外部からの入力

ユニット $i$ は，次式に基づいて活性值を更新する。 if $\left(\right.$ net $_{i}>0$ )

$\Delta a_{i}=\left(\max -a_{i}\right)$ net $_{i}-\operatorname{decay}\left(a_{i}-\right.$ rest $)$

otherwise,

$\Delta a_{i}=\left(a_{i}-\right.$ min $)$ net $_{i}-\operatorname{decay}\left(a_{i}-\right.$ rest $)$

ここで, $a_{i}:$ ユニット $i$ の活性值, $\max$ : 活

性值の最大值, $\min :$ 活性值の最小值, decay：活性値を rest に落ち着かせる割合， rest：ニニットに入力がないときに落ち着く 活性値

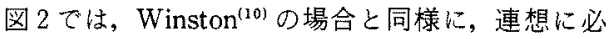
要なファクトのみが与えらているため, 容易に連想が
行われる。しかし，実際には各変数クラスタ内で相互 抑制による競合が行われ，これに勝ったアトムが連想 に用いられる。

\section{4. 計算機シミュレーション}

提案したコネクショニストモデルデータベースシス テムの有効性を確認するため, 計算機によるシミュレ ーションを行った。

$\langle 4 \cdot 1\rangle$ 計算機シミュレーション方法 シミュレ ーションに用いた条件は, 文献( 6 )の場合とほほ同じ にした。条件を以下に示す。

(1) $\max =1.0$

(2) $\min =-0.2$

(3) decay $=0.1$

(4) rest $=-0.1$

（5） $w_{i j}($ 興鹪性リンク） $=0.2$

(6) $w_{i j}$ (損制性リンク) $=-0.2$

図 3 にシミュレーションに用いたファクトの集合を 示す。概念の検索条件は、リスト(10)と同じとした。 すなうち，

$k b$ (mouse, smaller than, $X$ ) である。

以下，ネットワーク生成について手順を追って具体 的に説明する。

まず，連想の根拠になる四つの関係のテンプレート 構造は次のようになる。

$k b(Y$, ATTRIBUTE_NAME, mouse)

$$
\begin{array}{ll}
\mathrm{kb} \text { (banana, isa, food). } \\
\mathrm{kb} \text { (banana, color, yellow). } \\
\mathrm{kb} \text { (cat, eats, milk). } \\
1 \mathrm{~kb} \text { (cat, eats, mouse). } \\
\mathrm{kb} \text { (cat, hates, dog). } \\
2 \mathrm{~kb} \text { (cat, likes, mouse). } \\
5 \text { kb(cat, smaller,than, dog). } \\
6 \mathrm{~kb} \text { (cat, smaller,than, lion). } \\
\mathrm{kb} \text { (cheese, isa, food). } \\
\mathrm{kb} \text { (cheese, color, yellow). } \\
7 \mathrm{~kb} \text { (dog, hates, monkey). } \\
8 \text { kb(lion, eats, zebra). } \\
9 \mathrm{~kb} \text { (lion, likes, meat). } \\
3 \mathrm{~kb} \text { (man, hates, mouse). } \\
4 \mathrm{~kb} \text { (mickey, isa, mouse). } \\
\mathrm{kb} \text { (milk, isa, food). } \\
\mathrm{kb} \text { (milk, color, white). } \\
\mathrm{kb} \text { (mouse, eats, cheese). } \\
\mathrm{kb} \text { (mouse, eats, milk). } \\
\mathrm{kb} \text { (mouse, hates, cat). }
\end{array}
$$

図 3 シミュレーションに用いたファクトの集合 Fig. 3. Facts used for simulation. 
$k b(Z$, ATTRIBUTE_NAME, $X)$

$k b(Y$, smaller than, $Z)$

$k b$ (mouse, smaller than, $X$ )

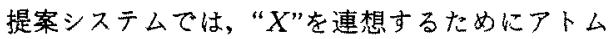

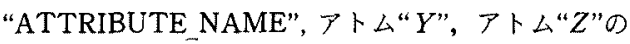
三つも同時検索する。

（1）リスト（18）により，アトム“mouse”を属性值 としてもつファクトを抽出する(ファクト1〜4)。

これらに関係する属性名“ATTRIBUTE_NAME” とそれに対応するアトム“Y”の二つの変数クラスタを 作る。

そして，各ファクトに基づいて対応するユニット間 (“Y”と“ATTRIBUTE_NAME”の間, “ATTRIBUTE NAME”と“mouse”の間)に双方向の興奮性のリンク を張る。

（2）リスト（20により，“smaller than”を属性名 としてもつファクトを抽出する(ファクト $5 \sim 6)$ 。 これらに関係するアトム“Z”の変数クラスタを作る。

そして各ファクトに基づいて，対応するユニット間 (“ $Y$ ”“smaller than”の間, “smaller than"と“ $Z$ ”の 間）に双方向の興鹪性のリンクを張る。

（3）リスト（19）に対応するファクトを抽出する (ファクト7〜9)。これらに関係するアトム“X”の変 数クラスタを作る。そして各ファクトに基づいて，対 芯するユニット間（“Z”と“ATTRIBUTE_NAME" の間, “ATTRIBUTE_NAME”と“ $X ” の$ 間) に双方 向の興奮性のリンクを張る。

（4）各クラスタ内のュニット間に双方向の㧕制性

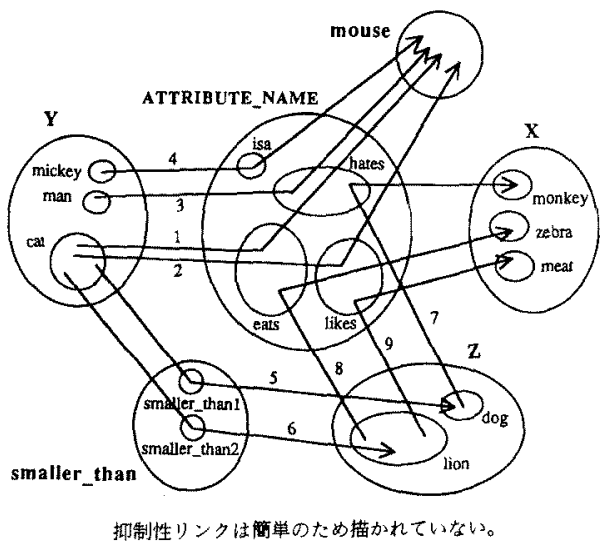

図 4 連想のために構成されたネットワーク

Fig. 4. Constructed network for association.
のリンクを張る。

ただし，検索条件リスト(リスト(21))を除く，同一 クラスタ内に含ま机る同名のアトムは，一つのニニッ トを共有する。

図 4 に，連想のために構成されたネットワークを示 す。図中の数字は，図 3 に坮汸るファクトと対応して おり，二つのノードを結ぶ線性すべて双方向の興篦性 リンクである。また，同一クラスタ内のノード間はす ベて抑制性のリンクで結合されている（図中では簡単 のため，抑制性リンクは示されていない。

〈4・2〉 シミュレーション結果および考察 図 5, 図 6 に，活性化拡散サイクルを行った場合の各クラス 夕内に扔けるュニットの活性度の時間変化を示す。

図 5 は, 各クラスタ内のニニットの初期值をずて 同じにした場合である。つ密り，文献（6)の場合と同 様に各コニットの初期值を,

概念ユニット： -0.1

制約ユニット： 0.3

とした場合である。ここで、制約ユニットを活性化し ておくのは，その制約が成立することを表している。 逆に概念ユニットを非活性化して扔くのは，まだその 概念が梌索すべき概念の一つの候補にすざないためで ある。これらの值注経験的に定めたものであり, 数学 的な根拠㤝ない。活性值の初期值の設定の仕方によっ ては検索の結果に微妙に影腤することもありうる(6)。 ただし、設定した值に近いかぎりシミンレーシ ヨンの結果はほとえど同じであった。ただし， “ATTRIBUTENAME”クラスタ内のユニットは変数 となっているため，概念ユニットと同様に扱った。図 より，競合がうまく行われていないクラスタがあるこ とがわかる。これは連想による推論を行う際に，構文 的な条件しか考慮していなかったからである。

図 6 は，連想に上る推論を行引際に，単語間の類似 度を考慮に入れた場合を示している。具体的には， “ATTRIBUTE”クラスタに扔いて, “eats”ユニットの 初期値を一0.1ではなく 0.3 としている。これは， “smaller_than”は, “likes”よりも“eats”のほうに近い という一種の連想処理を加えたことと等価である。同 図より，単語間の類似度を考慮した効果により，

$k b$ (mouse, smaller than, zebra) $\cdots \cdots(22)$ と, 推諭していることがわかる。そして次第に，構文 的な条件しか哮魔していない図 5 の場合の結果に近づ いていることがわかる。また，“eats”ュニットの初期 值に関しては一0.1よりも市る程度大きければ，連想 による推論が正しく行えることがシミュレーションよ 


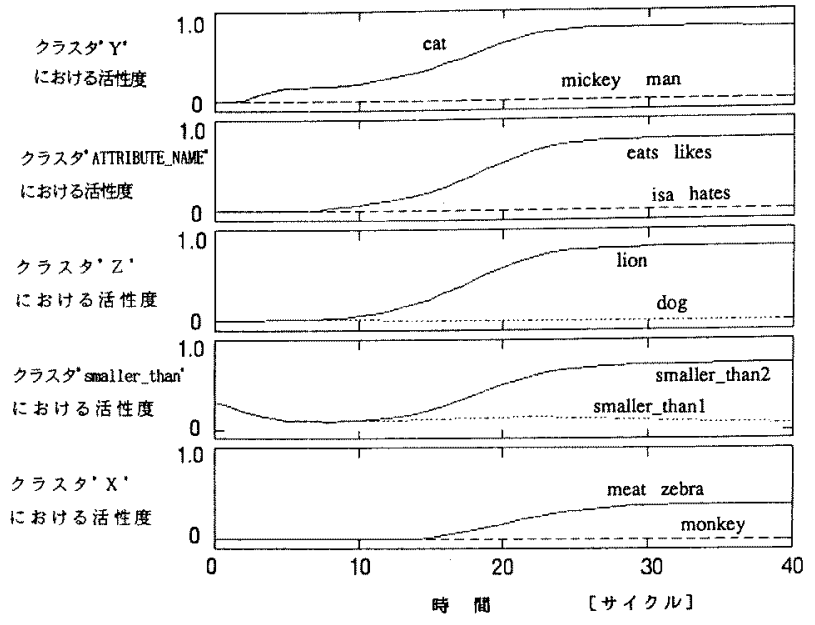

各タラスタ内て，活性度の初期值を等しくした場合。

図 5 各クラスタにおけるノードの活性度の時間変化

Fig. 5. The time course of activations of nodes in each cluster.

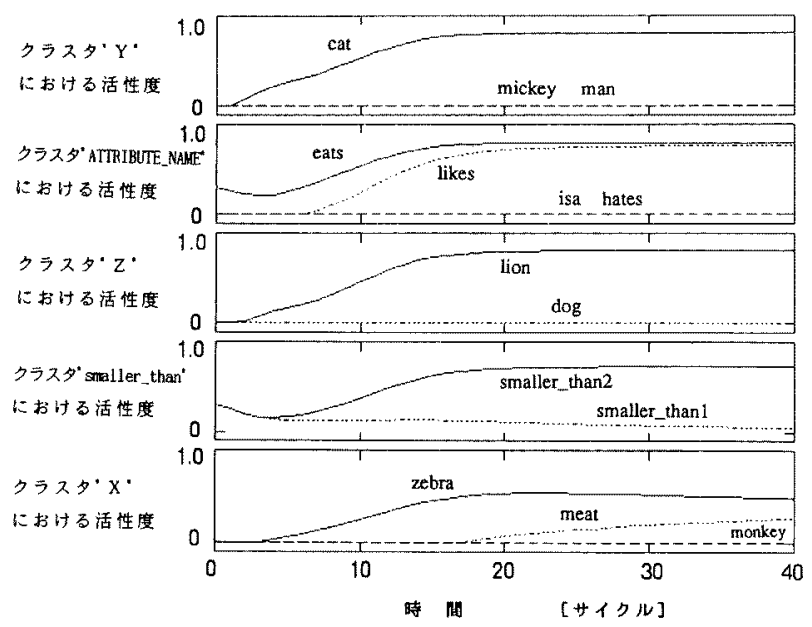

“eats”ノードたけ，活性度初期檤を一 0.1 加 0.3 に変更した場合。

図 6 各クラスタにおけるノードの活性度の時間変化

Fig. 6. The time course of activations of nodes in each cluster.

りかかった。

連想による推墖を行う際には，与えられた対象間で の類似性を考慮する必要がある。そのため図 5 の場合 のように構文的な類比だけの概念では，意味解积を考 えたうえでの連想をとらえることはできない(12)。従 つて, 与えられた対象間の類似性，すなわち単語間の 類似度についてのデータが重要となってくる。このよ うな研究は，自動翻訳機や電子化辞書などの需要の堌
大に伴って，最近特に活発になってきている(14)。ま た連想を行う際に，コネクショニストモデルによる連 想記憶モデル(15)(16)を用いる方法なども，今後有望で あると考えられる。

提案システムでは, 属性名が変数として用いられて いる。そのためネットワークを構成する際に“組合せ 的爆発”を起こすのでないかという危俱がある。しか し，属性名の抽出〔連想ネットワーク生成アルゴリズ 


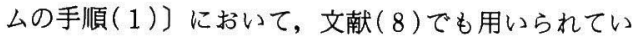
るようにコネクショニストモデルの連想記憶モデルな どを利用すれば，抽出するファクトの数を比較的容易 に制限できると考えられる。

\section{5. むす び}

本論文では，コネクショニストモデルを用いた連想 機能を有するデータベースシステムについて基礎的な 検討を行った。そして, 連想のためのテンプレート構 造を用いて動的にネットワークを構成した後，ユニッ トの活性化拡散サイクルにより連想を行うという方法 を提案した。更に, 計算機シミょレーションによって その有効性を確認した。

本方式は, 論理的なデータを扱うのが得意である人 工知能と, 比較的あいまいな情報を扱うのに適してい るコネクショニストモデルの両者の長所を利用してい る。提案した連想による推論機能を用いると, 頑丈 性, 文脈に依存した検索, 複数の概念の並列検索, デー タベースの保守性などの優れた特徴をすべて有するデ ータベースシステムの構築に貢献すると考えられる。

本論文で提案している連想のためのテンプレート構 造は極めて基本的なものである。従って，ほかにも 様々な構造のものが考元られ, それらにより更に高度 な推論などが可能になると考えられる。このように， 本論文梳不確かな推論や直観など，より人間的な知的 機能実現へ向けての貴重なアプローチにもなると考え られる。

本論文中で述べている連想処理については, 具体的 には文献(17)の Self-Organizing Semantic Maps の 利用を考えている。文献(17)では Feature Map を用 いて, 単語を意味の属性に従って空間的な配置として 分類している。従って, 距離の近い単語を調べることに よって連想処理を行うことは十分可能である。これは 現在研究中であり,その結果は別の機会に発表したい。

また,データベースシステムとしての無矛盾性と連 想処理との関係の解明や, 初期值の設定法などは今後 の課題として残されているが, 本研究に基づいて今後 その方向に研究を進めていきたい。

日ごろ御指導いただく本塾 中川正雄教授に梁く感謝 いたします。

(平成 3 年 4 月 5 日受付, 同 3 年 9 月 20 日再受付)

\section{文献}

(1) D. E. Rumelhart \& J. L. McClelland: Parallel Distributed Processing (1986) MIT Press

(2) A. Waibel, T. Hanazawa, G. Hinton, K. Shikano \& K. J.
Lang: "Phoneme recognition using time-delay neural networks", IEEE Trans. Acoustics, Speech, \& Signal Processing, 37, 328 (1989)

(3) K. Fukushima: "A neural network for visual pattern recognition", IEEE Computer, 21, 65 (1988)

(4) D. H. Ackley, G. E. Hinton \& T. J. Sejnowski: "A learning algorithm for boltzmann machines", Cognitive Science, 9, 147 (1985)

（5）古川：(相磯・甘利監修)「ノーペルコンピューティングへの 挑戦」,「論理プログラミング」第 4 章 (平2) 三田出版会

（6）萩原：「コネクショニストモデルを用いた知識ベースシステ 么」, 人工知能学会研資, SIG-KBS-8902-1, 1 (平元)

(7) D. L. Waltz \& J. B. Pollack: "Massively parallel parsing: A strong interactive model of natural language interpreta. tion", Cognitive Science, 9, 51 (1985)

(8)田村・安西：「Connectionist model を用いた自然言語処理 システム」, 情報処理学論, 28, 202（昭 62）

(9) D.S. Tourezky \& J.E. Hinton: "A distributed connectionist production system", Cognitive Science, 12, 423 (1988)

(10) P.H. Winston: "Learning and reasoning by analogy", Commun. ACM, 23, 689 (1980)

（11）䉓総研人工知能研究グループ, 他訳：類推学習（昭63）共 立出版

（12）原口・有川：「類推の定式化とその実現」, 人工知能学誌, 1, 132 (昭 61-9)

(13) 安西：認識と学習 (昭 64) 岩波書店

（14）丸山・原田・川本・紏野・諸橋・田村：「マイクロフィーチ ーャーに基づく語間の関連度の計算とその適合化」, 通信学会 研報, NLC $89-1,1$ (平元-5)

(15) K. Nakano: "Association - a model of associative memory", IEEE Trans. Systems, Man, \& Cybernetics, SMC-2, 380 (1972)

(16) Y.Hirai: "A model of human associative processor (HASP)", ibid., SMC-13, 851 (1983)

(17) H. Ritter \& T. Kohonen: "Self-Organizing Semantic Maps", Biol. Cybern., 61, 241 (1989)

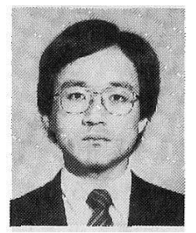

\section{萩 原 将 文 (非会員)}

昭和 62 年慶応義塾大学大学院工学研 究科博士課程修了。同年同大学助手, 平 成 2 年同講師, 現在に至る。工学博士。 通信用ディジタル信号処理, ニューラル ネットワークの研究に従事。電子情報通信学会, IEEE, INNS 会員。

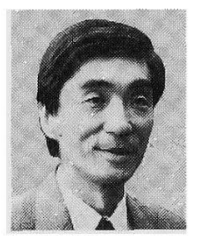

\section{安 西 祐一郎 (非会員)}

昭和 49 年慶応義塾大学大学院工学研 究科博士課程修了。 48 年同大学助手, 54 年同講師, 56 年カーネギー・メロン大 学客員助教授, 60 年北海道大学文学部 助教授, 63 年慶応義塾大学理工学部教授; 平成元年同大 学院計算機科学専攻教授兼任, 現在に至る。工学博士。情 報処理学会, 人工知能学会, IEEE, INNS 会員。 